\title{
Expert System For Diagnosing Hemophilia In Children Using Case Based Reasoning
}

\author{
${ }^{1}$ Subrianto Chandra, ${ }^{2}$ Sumijan, ${ }^{3}$ Eka Praja Wiyata Mandala \\ 1,2,3 Teknik Informatika, Universitas Putra Indonesia YPTK Padang \\ Email: ${ }^{1}$ subrianto.sc01@gmail.com, ${ }^{2}$ soe@ upiyptk.org, ${ }^{3}$ ekaprajawm@upiyptk.ac.id
}

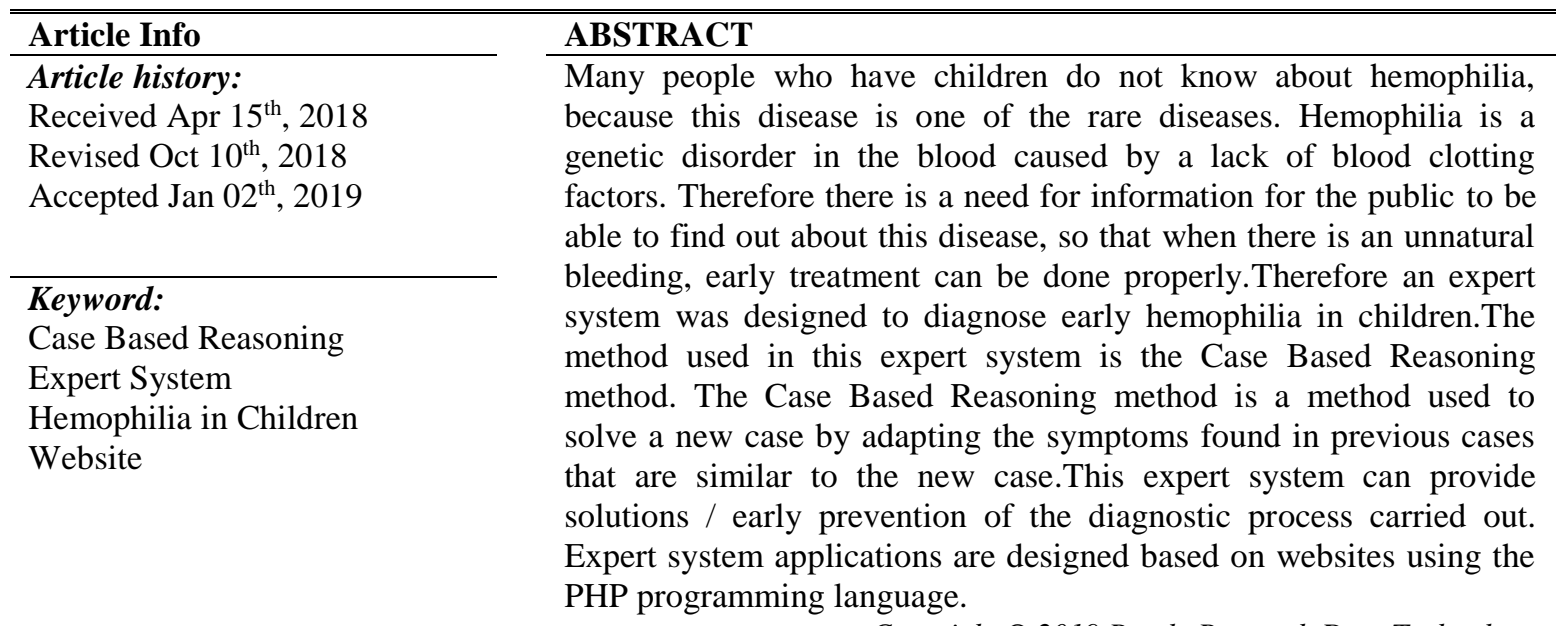

Corresponding Author:

Copyright $@ 2019$ Puzzle Research Data Technology

Subrianto Chandra

Teknik Informatika, Fakultas Ilmu Komputer

Universitas Putra Indonesia YPTK Padang

Jl. Raya Lubuk Begalung Padang, Sumatera Barat, Indonesia

Email: subrianto.sc01@gmail.com

DOI: http://dx.doi.org/10.24014/ijaidm.v2i1.6681

\section{PENDAHULUAN}

Banyak masyarakat yang mempunyai anak belum mengetahui tentang penyakit hemofilia, karena penyakit ini merupakan salah satu penyakit langka. Hemofilia merupakan penyakit kelainan genetik dalam darah yang disebabkan oleh kurangnya faktor pembekuan darah. Oleh karena itu ada kebutuhan akan informasi bagi masyarakat untuk dapat mengetahui tentang penyakit ini, sehingga ketika ada perdarahan yang tidak wajar, dapat dilakukan penanganan secara baik. Oleh karena itu dirancang sebuah sistem pakar untuk mendiagnosa awal hemofilia pada anak. Metode yang digunakan dalam sistem pakar ini adalah metode Case Based Reasoning. Metode Case Based Reasoning adalah metode yang digunakan untuk memecahkan kasus baru dengan mengadaptasi gejala yang ditemukan dalam kasus-kasus sebelumnya yang mirip dengan kasus baru. Sistem pakar ini dapat memberikan solusi / pencegahan awal dari proses diagnosa yang dilakukan.

Pada penelitian sebelumnya, metode Case Based Reasoning digunakan untuk memecahkan masalah pendiagnosaan penyakit hemofilia pada manusia dengan membaca pengalaman-pengalaman sebelumnya yang terjadi di masa lalu. Metode ini diterapkan untuk membangun sebuah sistem pakar untuk membantu manusia dalam mendiagnosa penyakit hemofilia [3]. Hemofilia merupakan salah satu jenis dari penyakit darah yang dialami oleh manusia [8]. Metode ini juga bisa digunakan untuk mendiagnosa penyakit yang diakibatkan oleh virus Eksantema [2], untuk mediagnosa penyakit jantung dan mendiagnosa penyakit Anoreksia Nervosa [5].

Penelitian yang dilakukan dilakukan saat ini, lebih menekankan pada penyakit hemofilia yang terjadi pada anak-anak. Berbeda dengan penelitian sebelumnya, yang membahas sistem pakar hemofilia pada manusia secara umum [3]. Penyakit hemofilia pada anak akan mempunyai gejala yang sedikit berbeda dengan yang dialami oleh orang dewasa. Sehingga sistem pakar yang dihasilkan pada penelitian ini, lebih fokus kepada anak-anak, sehingga akan memudahkan orang tua dalam melihat gejala awal dari penyakit hemofilia ini yang menyerang anak mereka dan orang tua akan memiliki pengetahun tentang bagaimana cara penanganan jika anak mereka terjangkiti oleh penyakit hemofilia ini. 
Perempuan pembawa sifat hemofilia yang menikah dengan laki- laki normal dapat menurunkan satu atau lebih anak lelaki penderita hemofilia atau satu atau lebih anak perempuan pembawa sifat. Sedangkan laki-laki penderita hemofilia yang menikah dengan perempuan normal akan menurunkan anak laki-laki yang normal atau anak perempuan pembawa sifat [6].

Pemecahan masalah yang ditawarkan pada penelitian ini adalah dibangunnya sebuah sistem pakar, dimana sistem pakar merupakan sistem yang mengadopsi keahlian pakar pada satu bidang yang dimasukkan ke dalam sistem yang digunakan oleh pengguna yang bukan pakar [1]. Sistem pakar memiliki enam konsep dasar yaitu pakar itu sendiri, adanya kepakaran dari seorang pakar, terjadinya pemindahan kepakaran dari pakar ke pengguna, menggunakan mesin inferensi, bekerja berdasarkan aturan yang sudah ditetapkan dan mempunyai kemampuan untuk menjelaskan [9].

Metode yang digunakan pada penelitian ini adalah case based reasoning yang merupakan metode untuk menyelesaikan kasus baru dengan cara mengadaptasi solusi-solusi yang terdapat pada kasus-kasus sebelumnya yang mirip dengan kasus baru tersebut [5].

Tujuan dari penelitian yang dilakukan ini adalah agar orang tua bisa lebih cepat mengetahui dan mengantisipasi terjangkitnya penyakit hemofilia pada anak. Karena jika tidak ditangani dengan cepat dan serius, akan berakibat fatal bagi anak tersebut. Sistem pakar yang dihasilkan akan membantu orang tua dalam pendiagnosaan awal terhadap penyakit hemofilia pada anak dalam bentuk konsultasi.

\section{METODE PENELITIAN}

Penelitian yang dilakukan harus menggunakan metode agar alur penelitian bisa lebih jelas dan terarah. Metode penelitian yang digunakan adalah metode pengembangan perangkat lunak seperti yang digambarkan pada gambar 1 :

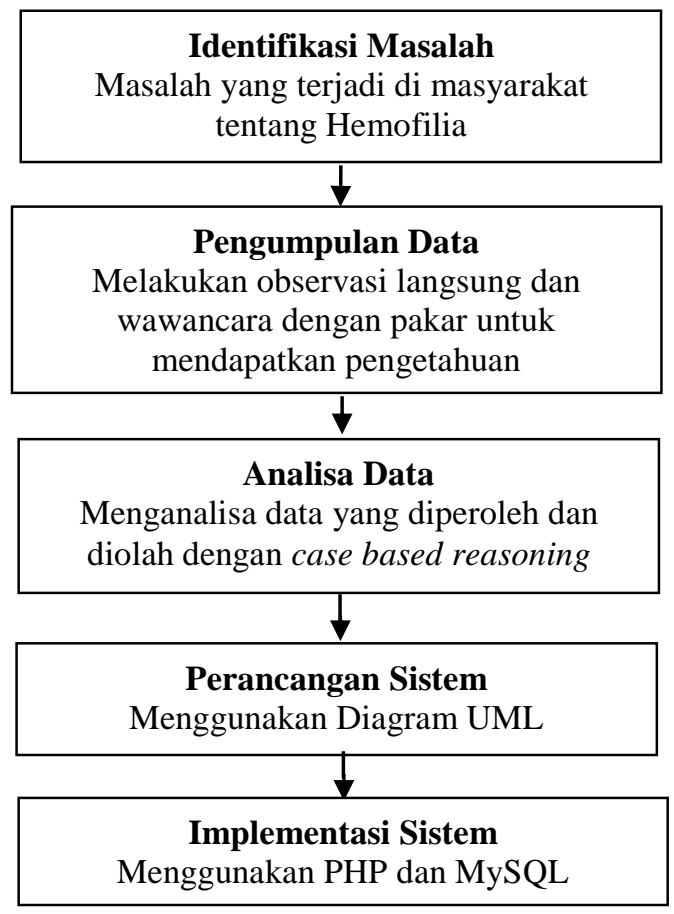

Gambar 1. Kerangka Penelitian

Penelitian dimulai dari mencari dan mengidentifikasi masalah tentang kejadian hemofilia pada anak. Masalah biasanya diperoleh dari orang tua yang memiliki anak yang menderita penyakit hemofilia dengan cara menemui orang tua tersebut dan melakukan wawancara. Setelah masalah diketahui, dilakukan pengumpulan data tentang penyakit hemofilia tersebut. Data diperoleh dari pakar yang sudah pernah menangani penykit hemofilia pada anak yaitu seorang dokter. Data yang diperoleh berupa data tentang dan penyakit hemofilia serta bagaimana cara penanganannya. Data yang sudah diperoleh, kemudian dianalisa dan dilakukan proses inferensi dengan menggunakan metode case based reasoning yang terdiri dari empat siklus dalam pemecahan masalah adalah retrieve, reuse, revise dan retain [3]. Langkah selanjutnya adalah perancangan sistem pakar dengan memakai diagram dalam UML, yaitu use case diagram yang merupakan hubungan antara aktor dengan keseluruhan use case dalam sistem [7]. Selanjutnya diimplementasikan ke dalam bentuk aplikasi yang dibuat berbasis web menggunakan bahasa pemrograman PHP dan ditunjang 
mendia penyimpanan MySQL sebagai basis datanya sehingga sistem pakar ini bisa digunakan oleh semua orang tua yang khawatir apakah anak mereka menderita hemofilia atau tidak [4].

\section{HASIL DAN PEMBAHASAN}

Penelitian melibatkan pakar seorang dokter yang menjelaskan bahawa terdapat tiga jenis penyakit Hemofilia pada anak yaitu Hemofilia Berat, Hemofilia Sedang dan Hemofilia Ringan dengan total 14 gejala.

\subsection{Proses Retrieve}

Proses retrieve adalah menemukan kasus yang sama atau yang paling mirip dengan kasus baru Pencarian kemiripan tersebut dilakukan dengan cara mencocokkan gejala yang di inputkan oleh user dengan gejala yang ada pada basis pengetahuan.

Pada awal proses diagnosa user akan mengisi gejala-gejala yang dialaminya, selanjutnya pengguna akan mendapatkan hasil diagnosa. Sistem akan melakukan pembobotan dengan melakukan pencocokan satu per satu antara gejala-gejala yang ada didalam basis pengetahuan. Adapun rumus pemrosesan kemiripan bobot yang dilakukan dapat ditunjukkan pada persamaan 1:

$$
\text { Similiarity }=\frac{s 1 * w 1+s 2 * w 2+\cdots s n * w n}{w 1+w 2+\cdots w n}
$$

Contohnya penyakit Hemofilia Sedang (P02) memiliki gejala:

1. Memar yang membekas di kulit saat benturan dan lama hilang (G07)

Bobot : 8

2. Kesemutan di pergelangan kaki / siku / lutut (G08)

3. Nyeri di pergelangan kaki / lutut / siku (G09)

4. Pendarahan otot / sendi karena benturan (G10)

5. Riwayat keluarga ada yang menderita penyakit Hemofilia (G06)

6. Pembengkakan (G11)

Penyakit Hemofilia Ringan (P03) memiliki gejala:

1. Pendarahan yang tidak berhenti pasca operasi seperti sunat (G12)

Bobot : 8

2. Pendarahanyang tidak berhenti pasca proses pencabutan gigi (G13)

Bobot : 8

3. Mengalami luka yang sulit berhenti (G14)

4. Pendarahan otot / sendi karena benturan (G10)

5. Riwayat keluarga ada yang menderita penyakit Hemofilia (G06)

Bobot : 3

Bobot : 8

Fakta yang diberikan orang tua diketahui seperti berikut :

1. Mimisan mendadak dan sulit berhenti (G01)

2. Riwayat keluarga ada yang menderita penyakit Hemofilia (G06)

3. Kesemutan di pergelangan kaki / siku / lutut (G08)

4. Nyeri di pergelangan kaki / lutut / siku (G09)

5. Pendarahan otot/ sendi karena benturan (G10)

Untuk penyakit Hemofilia Sedang (P02), maka proses perhitungannya adalah:

$$
\begin{aligned}
\operatorname{Similiarity}(x, x) & =\frac{s 1 * w 1+s 2 * w 2+\cdots s n * w n}{w 1+w 2+\cdots w n} \\
& =\frac{(1 * 8)+(1 * 8)+(1 * 3)+(1 * 3)+0}{8+3+3+8+8+3} \\
& =\frac{22}{33}=0,667 \\
& =\mathbf{6 6 . 7} \%
\end{aligned}
$$

Dari perhitungan kasus diatas tingkat kemiripan dengan kasus lama. sebesar $66.7 \%$

Untuk penyakit Hemofilia Ringan (P03), maka proses perhitungannya adalah :

$$
\begin{aligned}
\operatorname{Similiarity}(x, x) & =\frac{s 1 * w 1+s 2 * w 2+\cdots s n * w n}{w 1+w 2+\cdots w n} \\
& =\frac{(1 * 8)+(1 * 8)+0+0+0}{8+8+8+3+8} \\
& =\frac{16}{35}=0.457 \\
& =\mathbf{4 5 . 7 \%}
\end{aligned}
$$


Dari perhitungan kasus diatas tingkat kemiripan dengan kasus lama. sebesar $\mathbf{4 5 . 7} \%$

\subsection{Proses Reuse}

Dari kasus diatas, kasus yang memiliki bobot kemiripan tertinggi dengan kasus lama adalah Hemofilia Sedang (P02) dengan nilai 66.7\%. Pada proses reuse, solusi yang diberikan adalah solusi dengan bobot kemiripan kasus yang ada pada pengetahuan dengan kasus baru yang paling tinggi.

\subsection{Proses Revise}

Dilakukan untuk memperbaiki solusi kemudian disimulasikan dan diperlukan kembali untuk memperbaiki solusi tersebut agar cocok dengan kasus yang baru.

\subsection{Proses Retain}

Proses retain menyimpan pengalaman untuk memecahkan masalah yang akan datang kedalam basis kasus. Setelah melakukan perhitungan dengan metode Case Base Reasoning, maka akan dirancang aplikasi sistem pakar dengan menggunakan perancangan awal dengan use case diagram. Berikut ini adalah desain use case diagram yang ditunjukkan gambar 2 :

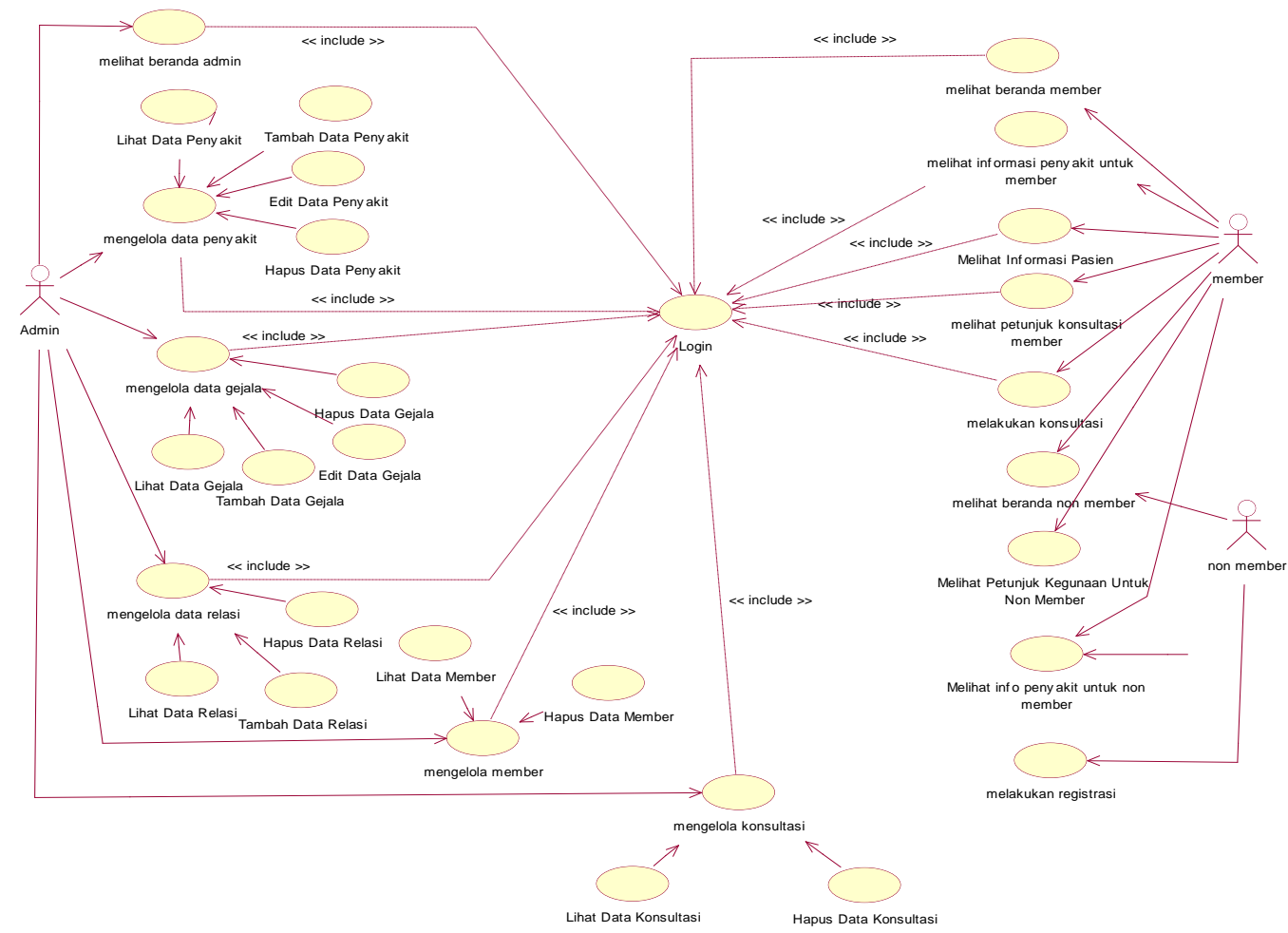

Gambar 2. Use Case Diagram

Gambar 2 menjelaskan hubungan antara aktor yang terlibat dalam sistem pakar yaitu Admin sebagai pengelola sistem pakar, Member sebagai anggota yang bisa melakukan konsultasi dan Non Member yang hanya bisa melihat informasi seputar Hemofilia saja tetapi tidak bisa melakukan konsultasi.

Setelah proses perancangan, proses implementasi dimulai dengan membuat program sistem pakar dengan Bahasa pemrograman berbasis web yaitu PHP dan ditunjang dengan basis data MySQL sebagai media penyimpanan data.

Gambar 3 menggambarkan bentuk antar muka halaman konsultasi dari sistem pakar. 


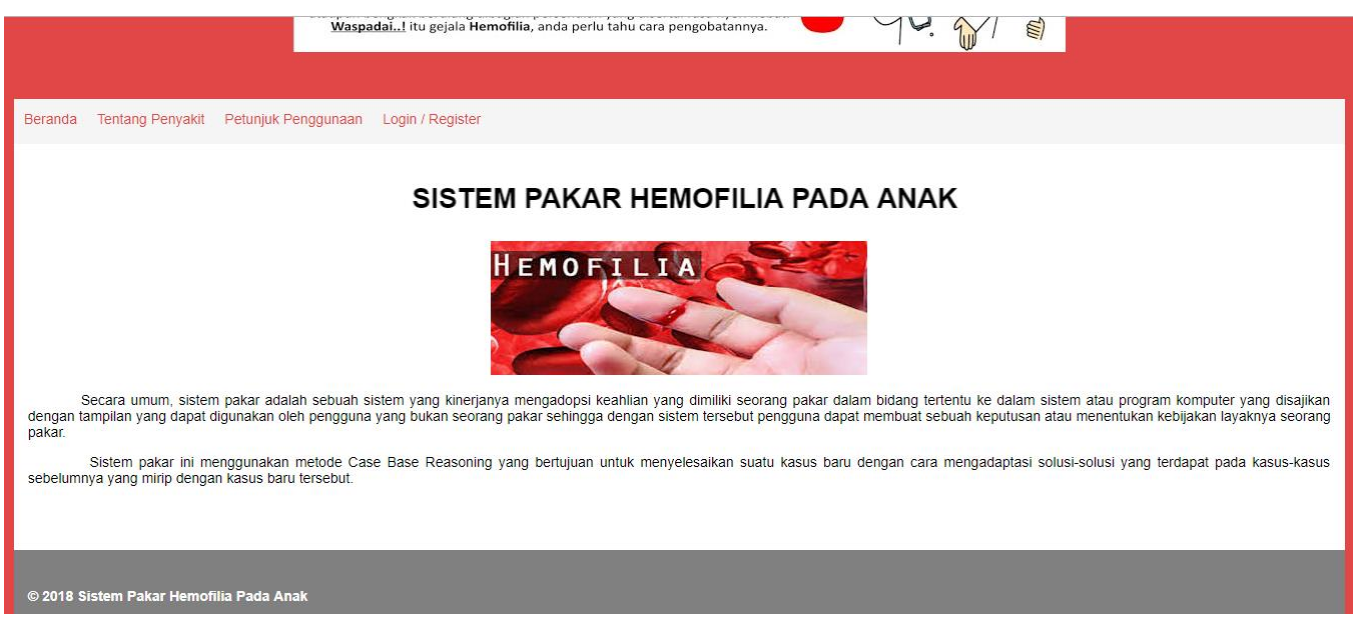

Gambar 3. Halaman Utama Sistem Pakar

Gambar 3 menggambarkan halaman utama dari sistem pakar yang bisa diakses oleh semua aktor yaitu Admin, Member dan Non Member. Jika akan melakukan konsultasi, Non Member harus mendaftar terlebih dahulu. Setelah terdaftar sebagai Member, maka halaman konsultasi sudah bisa diakses seperti Gambar 4.

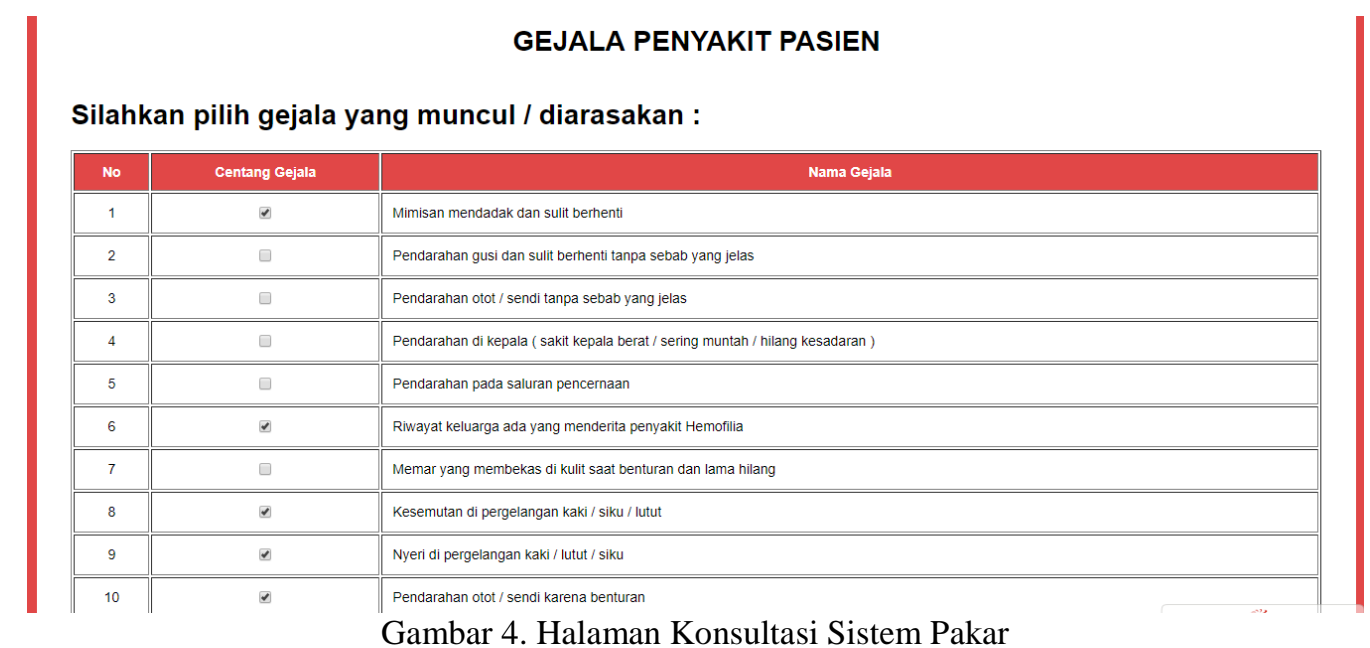

Gambar 4 menampilkan semua gejala yang bisa dipilih oleh Member sesuai dengan gejala yang dialami oleh anak. Setelah gejala dipilih, Member bisa menekan tombol konsultasi, maka sistem pakar akan memproses gejala yang dimasukkan, sehingga akan muncul hasil konsultasi seperti Gambar 5

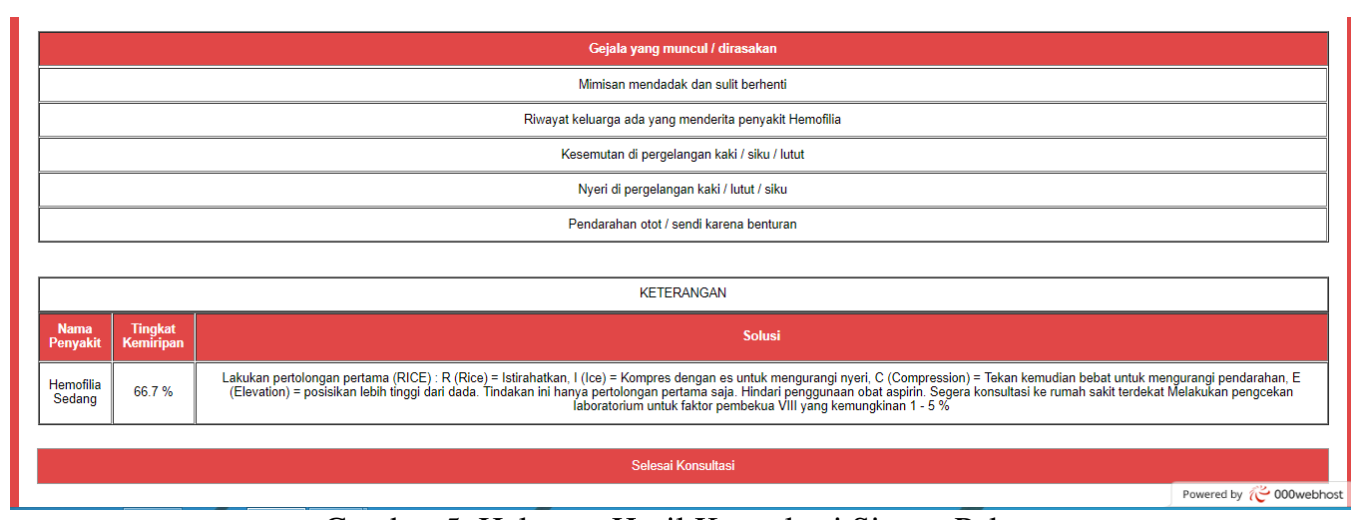

Gambar 5. Halaman Hasil Konsultasi Sistem Pakar

Gambar 5 memberikan informasi yang lengkap kepada Member tentang hasil dari konsultasu sistem pakar yang sudah dilakukan. 


\section{KESIMPULAN} berikut:

Setelah sistem pakar diimplementasikan, maka dapat diperoleh beberapa kesimpulan sebagai

1. Sistem pakar dapat mempermudah orang tua yang memliki anak dalam mengetahui tentang informasi penyakit hemofilia pada anak melalui konsultasi sistem pakar

2. Sistem pakar dapat membantu orang tua dalam melakukan diagnosa awal penyakit hemofilia pada anak.

3. Sistem pakar dapat memberikan solusi / pencegahan awal yang dilakukan orang tua dalam menghadapi penyakit hemofilia pada anak.

\section{REFERENSI}

[1] Andriani A. Pemrograman Sistem Pakar Konsep Dasar dan Aplikasinnya Menggunakan Visual Basic 6. Yogyakarta: MediaKom. 2012.

[2] Aribowo AS. Pengembangan Sistem Cerdas Menggunakan Penalaran Berbasis Kasus (Case Based Reasoning) Untuk Diagnosa Penyakit Akibat Virus Eksantema. Telematika. 2015; 7(1).

[3] Gulo AAHS, Syahrizal M. Perancangan Aplikasi Sistem Pakar Mendiagnosa Penyakit Hemofilia Pada Manusia Menerapkan Metode Case Based Reasoning. Pelita Informatika: Informasi dan Informatika 2018. 17(1)

[4] Mandala EPW. Web Programing Project 1: epwm Forum. Yogyakarta: Andi. 2015.

[5] Nasution SW, Hasibuan NA, Ramadhani P. Sistem Pakar Diagnosa Anoreksia Nervosa Menerapkan Metode Case Based Reasoning. KOMIK (Konferensi Nasional Teknologi Informasi dan Komputer). $2017 ; 1(1)$

[6] Permono B. Buku Ajar Hematologi - Onkologi Anak. Jakarta: Badan Penerbit IDAI. 2012

[7] Sukamto RA, Shalahuddin M. Modul Pembelajaran Rekayasa Perangkat Lunak (Terstruktur dan Berorientasi Objek). Bandung: Informatika. 2013.

[8] Silmi M, Sarwoko EA, Kushartantya, Sistem Pakar Berbasis Web dan Mobile Web untuk Mendiagnosis Penyakit Darah pada Manusia dengan Menggunakan Metode Inferensi Forward Chaining. Journal of Informatics and Technology, 2013; 2 (3) : 42-49

[9] Sutojo T, Mulyanto E, Suhartono V, Kecerdasaan Buatan, Yogyakarta : Andi, 2011

[10] Yoshua V, Angliadi E. Rehabilitasi Medik Pada Hemofilia. Jurnal Biomedik, 2013; 5(2).

\section{BIBLIOGRAFI PENULIS}

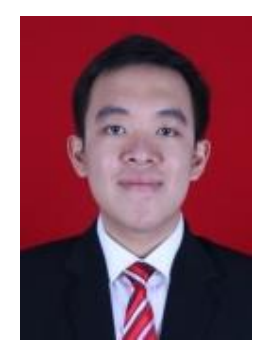

Subrianto Chandra yang biasa dipanggil Brian, lahir di Padang, 1 April 1997. Kuliah di jurusan Teknik Informatika Fakultas Ilmu Komputer Universitas Putra Indonesia "YPTK" Padang masuk pada tahun 2015 dan menyelesaikan studi pada tahun 2019

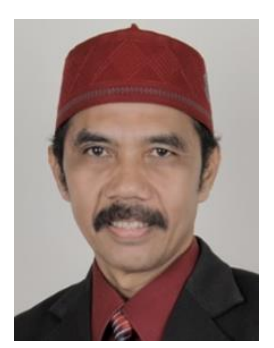

Dr. Ir. Sumijan, M.Sc lulusan dari AMIK YPTK Padang yang sekarang menjadi Universitas Putra Indonesia YPTK Padang. Melanjutkan studi S2 di Universiti Teknologi Malaysia. Menamatkan program Doktor di Universitas Gunadarma Jakarta. Saat ini menjadi staf pengajar di program studi Teknik Informatika, Universitas Putra Indonesia YPTK Padang. 


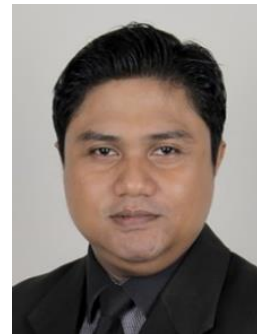

Eka Praja Wiyata Mandala, S.Kom, M.Kom lulusan S1 Teknik Informatika dari Universitas Indonusa Esa Unggul Jakarta pada 2008. Lulus S2 Teknik Informatika di Universitas Putra Indonesia YPTK Padang pada 2011. Saat ini menjadi staf pengajar di program studi Teknik Informatika, Universitas Putra Indonesia YPTK Padang. 